\title{
Assessment of Drought Recurrence in Somaliland: Causes, Impacts and Mitigations
}

\section{Abdulkadir $\mathbf{G}^{*}$}

Food and Agriculture Organization of the United Nations, Koddbur, Hargeisa, Somaliland

"Corresponding author: Abdulkadir G, Food and Agriculture Organization of the United Nations, Koddbur, Hargeisa, Somaliland, Tel: 0633157426; E-mail: Abdulkadir.Gure@fao.org

Received date: Apr 06, 2017; Accepted date: Apr 17, 2017; Published date: Apr 29, 2017

Copyright: (c) 2017 Abdulkadir G. This is an open-access article distributed under the terms of the Creative Commons Attribution License, which permits unrestricted use, distribution, and reproduction in any medium, provided the original author and source are credited.

\begin{abstract}
This paper presents a comprehensive review and analysis of the available climatological data and information on droughts to examine the major causes of droughts recurrence in Somaliland by analyzing the drought occurrence in the past decades with special focus on drought categories and its impact on the livelihoods and sustainable development of Somaliland. The primary data used for this study was collected from the rainfall stations across Somaliland as well as climate data retrieved from CHIRPS gridded rainfall dataset. However, the main findings of the present study were; Somaliland is characterized by drought, which is known to have the most far-reaching impacts of all natural disasters. This obvious challenge is most likely to aggravate due to slow progress in drought risk management, increased population and massive land degradation. The study also found that after a large scale failure of the rains during the 2016 Deyr season have led to severe drought conditions across Somaliland, resulting in extensive growing season failures and record low vegetation. The most seriously affected areas in this current drought are the eastern regions. On the other hand, based on the available climatological data from the past, it clearly shows that Somaliland is likely to face extreme and widespread droughts in the coming years as climate change is anticipated to increase the intensity and frequency of drought. As a result, there is a clear need for increased and integrated efforts in drought mitigation to lessen the negative impacts of recurrent droughts.
\end{abstract}

Keywords: Variability coefficient; Precipitation; Standard deviation

\section{Introduction}

Based on Palmer [1], drought is defined as permanent (from the beginning times of droughts until the end of the duration) and unusual deficit of moisture and is classified into four interrelated categories. The first type is called Meteorological drought and is defined by climatic variables (precipitation and humidity) and the duration of the dry period. Hydrological drought which is the second type of drought is associated with the effects of periods of rainfall shortfalls on the water levels of rivers, reservoirs and lakes and aquifers.

The third type is Agricultural drought which occurs when there is not enough water available for a particular crop to grow in a particular time. It is important to mention that Agricultural drought is normally evident after meteorological drought but before a hydrological drought. In general, drought is a complex phenomenon, which varies every time in terms of its onset, intensity, duration and geographical coverage and causes a serious hydrological imbalance [2].

In Horn of Africa, drought and its consequences (degradation of environmental and natural resources), continues persistent largely due to climate changes, increased human population, inadequate institutional capacities, civil unrest and high poverty levels in the region [3]. In Somaliland, which lies in an arid and semi-arid environment, is frequently experienced recurrent episodes of drought which has become serious natural hazards.

It affects large proportion of the population in a number of ways such as causing loss of life, crop failures, food shortages which might lead to malnutrition, health problems and mass migration. The most seriously affected areas are eastern regions namely Sanaag, Sool and
Togdheer. These regions face frequent reduction of water and moisture. However, in the current drought (2015-2016), most of the regions of Somaliland suffering the worst drought in several decades which represents the most severe food security emergency.

Two consecutive seasons (Gu and Deyr) of significantly below average rainfall in Somaliland have resulted in failed crop production, depletion of grazing resources and significant livestock mortality. Pastoralists and agro-pastoralists who occupy the vast majority in Somaliland are hardly meet basic water requirements during the current drought and the problem will most likely get worse due to the climate change.

In this study, the main purpose is merely to investigate the major causes and impacts of drought recurrence in Somaliland and its outcome is expected to add up to the understanding the causes of the deepening marginalization and vulnerability of the Somaliland pastoralists due to the recurrent droughts and facilitate the mitigation of future droughts.

\section{Study Area}

The geographical coverage of the study area is the self-declared state of Somaliland that broke away from Somalia in 1991, declaring independence using the borders of the former British Somaliland (Figure 1). To date, Somaliland has not been recognized by the international community as well as the federal government of Somalia.

However, since its establishment, Somaliland has been enjoying peace, working political system and survived much of the chaos and violence that overwhelmed the rest of Somalia. 


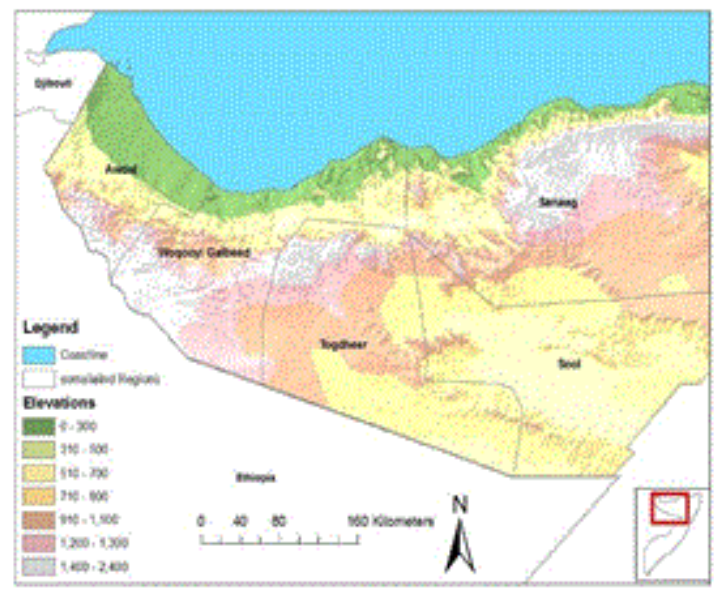

Figure 1: Location of the study area with elevation above the sea level.

Pastoralism has been the major livelihood of Somaliland whereby populations with their livestock follow seasonal migration patterns depending upon rainfall and pasture availability. Nevertheless, for the past decades, there has been a dramatic changes in the socio-economy of the pastoral population as a result of the recurring droughts and massive change of land use, which in turn had negative impacts on availability of fodder, and thus adversely affecting livestock production.

\section{Climate}

Generally, Somaliland has an arid to semi-arid climate, with four seasons. The first main rainy season of $\mathrm{Gu}$ occurs between April and June, when around $50-60 \%$ of rain falls. The second rainy season is called Deyr (from August to November) and accounts 20-30\% of total rainfall. The two dry seasons in are Jilaal and Hagga, which occur between December and March and July and August, respectively (Table 1).

The amount of rainfall received annually reduces further to the north except for areas around Sheikh, Hargeisa and Borama that receive between $500 \mathrm{~mm}$ and $600 \mathrm{~mm}$ per year [4]. While the area around Erigavo receives up to $400 \mathrm{~mm}$ annually [5]. The northern coastline is characterized by low rains of less than $100 \mathrm{~mm}$ per year. The rest of Somaliland receives an annual rainfall of 200-300 mm [4]. In the higher altitudes of the mountains and plateau areas temperatures vary considerably with the seasons, with a mean annual temperature of $20-24^{\circ} \mathrm{C}$, while the coastal region has mean annual temperatures of $28-32^{\circ} \mathrm{C}$.

\begin{tabular}{|c|c|c|c|c|c|c|c|c|c|c|c|c|c|}
\hline $\begin{array}{l}\text { Rainfall } \\
\text { Station }\end{array}$ & Jan & Feb & Mar & Apr & May & Jun & Jul & Aug & Sep & Oct & Nov & Dec & Annual \\
\hline Aburin & 4.3 & 12 & 29.3 & 77.5 & 65.2 & 38.4 & 50.6 & 68.3 & 66.4 & 31.6 & 11.1 & 3.2 & 457.8 \\
\hline Borama & 4.3 & 19.6 & 41.9 & 96.3 & 59.3 & 31.3 & 68 & 103.7 & 78.3 & 20.6 & 10.3 & 3.8 & 537.2 \\
\hline Burao & 2.9 & 2.5 & 11.1 & 71.9 & 65.2 & 7.8 & 4.7 & 3.8 & 7.9 & 88.5 & 61.7 & 8.2 & 336.3 \\
\hline Caynabo & 2.9 & 4.4 & 11.9 & 48.7 & 55.3 & 17.1 & 9.5 & 15.2 & 33.2 & 37.9 & 12.7 & 3.2 & 251.9 \\
\hline Dilla & 5 & 13.9 & 36.4 & 75.3 & 65.2 & 47.7 & 72.7 & 94.9 & 72.7 & 25.3 & 11.9 & 3.2 & 524 \\
\hline Eeerigavo & 7.8 & 6.3 & 18.2 & 34.3 & 51.4 & 30.6 & 6.3 & 25.3 & 64.8 & 7.1 & 4.7 & 1.3 & 258.2 \\
\hline Elfweyne & 3.6 & 4.4 & 11.9 & 34.3 & 45.5 & 18.5 & 7.9 & 17.7 & 37.2 & 21.3 & 7.1 & 1.9 & 211.2 \\
\hline Gebilley & 1.4 & 6.3 & 30 & 57.6 & 61.3 & 50.5 & 71.2 & 84.7 & 62.5 & 19 & 9.5 & 1.9 & 455.8 \\
\hline Hargeisa & 2.9 & 10.6 & 26.1 & 80.8 & 65.2 & 34.2 & 42.7 & 58.2 & 64.8 & 30.8 & 9.5 & 1.9 & 427.8 \\
\hline Odweyne & 3.6 & 8.2 & 21.3 & 59.8 & 59.3 & 28.5 & 26.9 & 40.5 & 50.6 & 35.6 & 11.1 & 4.43 & 349.6 \\
\hline Quljeed & 6.4 & 19 & 39.5 & 84.1 & 63.2 & 39.8 & 71.2 & 102.5 & 75.9 & 25.3 & 13.4 & 3.8 & 544.1 \\
\hline Sheikh & 4.3 & 10.8 & 27.7 & 69.7 & 67.2 & 33.4 & 28.5 & 46.8 & 64 & 56.9 & 19.8 & 11.4 & 440.4 \\
\hline
\end{tabular}

Table 1: Somaliland long-term average rainfall for selected stations.

\section{Soils}

Soil types of Somaliland closely follow its geomorphology and are characterized by poor structure, high permeability, low moisture retention ability and inadequate internal drainage [6]. Moreover, soil erosion has been a major challenge as a result of land clearing, cutting trees for charcoal production and overgrazing of livestock. Gully erosion is a also another major challenge to both rain fed farming land and grazing land and has made large parts of farming land in Somaliland unproductive and is spreading at an alarming rate [6].

\section{Land Use}

In Somaliland, land is mainly used for livestock production and rearing or mix farming (crop and livestock production). Most of the regions in Somaliland are dry and cannot support rain fed agriculture except for small pockets of land in the areas around Hargeisa, Gebiley and Borama that receive amounts of rainfall that can support rainfall dependent agriculture. The eastern regions of Togdheer, Sool, and Sanaag are almost exclusively relying on livestock raising [6]. The coastal grasslands are used for extensive livestock grazing especially in 
the dry season as water is more available in these areas than in the wood land [6].

\section{Methods}

\section{Data}

The primary data used for this study was collected from the meteorological stations of Somaliland managed by the Department of Meteorology and Food Security of the Ministry of Agriculture which is technically and financially supported by the FAO-SWALIM. It was also used CHIRPS gridded rainfall dataset produced by the Climate Hazards Group at the University of California, Santa Barbara.

The Climate Hazards Group Infrared Precipitation with Station data (CHIRPS v.2) is a global daily, pentadal and monthly precipitation product explicitly designed for monitoring agricultural drought and global environmental change over land [7]. The CHIRPS is a gridded rainfall time series that brings together high-resolution average rainfall data gleaned from satellites and weather station data to provide a comprehensive picture of rainfall patterns from 1981 to the nearpresent. In addition, there were a secondary data used for this study collected from previous reports and literature (Figure 2).

It was also carried out statistical and situational analysis by holistically evaluating the available information on drought and rainfall data to compile a picture of the current drought situation in Somaliland.

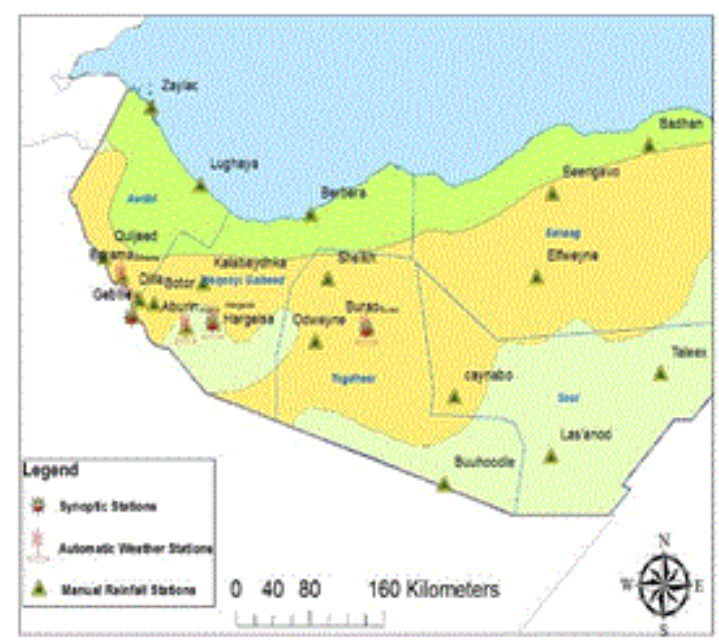

Figure 2: Location of the meteorological networks in Somaliland.

\section{Standardized Precipitation Index (SPI)}

Standardized Precipitation Index (SPI) is used to indicate meteorological drought, which is mainly caused by a deficiency of precipitation. McKee et al. [8] suggested that the SPI ranges corresponding to different severity levels of drought (Table 2). The SPI calculation for any location is based on the long-term precipitation record for a desired period. A positive SPI value indicates greater than mean precipitation while a negative value indicates less than mean precipitation.
The SPI has been used to analyse drought severity in different parts of the world. It has been used in Australia [9], in Karnataka, India [10], in Mexico [11], in Iran [12] and among other places in the world and is calculated as follows:

$$
\text { Spi }=\frac{X-\bar{X}}{\sigma}(1)
$$

Where: $\sigma=$ Standard deviation

\section{$\mathrm{X}=$ Precipitation}

$\bar{X}=$ Mean precipitation.

\begin{tabular}{|l|l|l|}
\hline No. & SPI & Climate Situation \\
\hline 1 & $>2$ & Intensely moist \\
\hline 2 & 1.5 to -1.49 & Very moist \\
\hline 3 & 1 to -1.49 & Moderately moist \\
\hline 4 & 0 to -0.99 & Low moisture \\
\hline 5 & 0 to -0.99 & Mild drought \\
\hline 6 & -1 to -1.49 & Moderate drought \\
\hline 7 & -1.5 to -1.99 & Severe drought \\
\hline 8 & $<2$ & Intense drought \\
\hline
\end{tabular}

Table 2: SPI index values and the drought intensity.

\section{GeoCLIM}

The GeoCLIM program is part of a set of agro- climatic analysis products developed by the FEWS NET and United States Geological Survey (USGS). This is a spatial analysis tool designed for climatological analysis of historical rainfall and temperature and evapotranspiration data.

It can be used to blend station information with satellite data to create improved datasets and analyse seasonal trends and historical climate data. Moreover, the GeoCLIM is also used to examine drought for a selected region by calculating the standardized precipitation index (SPI). In this paper, it was also used GIS (geographical information system) tool to produce a wide range of different maps of the study area.

\section{Results}

For the past decades, Somaliland has seen an increase in hazardous events such as droughts, flash floods, massive land degradation, and invasion of alien species. However, drought remains the only major disaster causing huge damages to its populations and the economy. Currently, drought conditions still prevail in most parts of Somaliland particularly in the eastern regions which had a poor rainfall performance in the previous Deyr and Gu rainy seasons. In some areas of Sanaag, Togdheer and Sool regions, drought conditions have persisted even longer and spread to western regions of Somaliland.

Therefore, in order to understand why intense dry and below normal rainy seasons in 2016 turn into crises in 2017, we need to look beyond the shortage of rain. In this paper, it was analyzed the performance of the 2016 Deyr and Gu rainfall activities as well as the 
Page 4 of 12

historical drought disasters in Somaliland to find out the actual causes of the current drought.

It is evident from the analysis that throughout its recent history, Somaliland has experienced 15 major droughts during the period between 1960 and 2017 as indicated in Table 3. The droughts that occurred in 1973-1974, 1984, 1991, 2010/2011 and 2016/2017 were most intense and widespread.

\begin{tabular}{|l|l|}
\hline Disaster & Date \\
\hline Drought & 1964 \\
\hline Drought & $1973 / 1974$ \\
\hline Drought & $1979 / 1980$ \\
\hline Drought & 1984 \\
\hline Drought & 1987 \\
\hline Drought & 1991 \\
\hline Drought & 1994 \\
\hline Famine & 36220 \\
\hline
\end{tabular}

\begin{tabular}{|l|l|}
\hline Drought & 36526 \\
\hline Drought & 37043 \\
\hline Drought & 37226 \\
\hline Drought & $2003 / 2004$ \\
\hline Drought & $2006 / 2007$ \\
\hline Drought & $2010 / 2011$ \\
\hline Drought & $2016 / 2017$ \\
\hline
\end{tabular}

Table 3: Historical drought disasters in Somaliland.

However, the analysis of droughts during in the specified period indicated that droughts have intensified in terms of their frequency, severity and coverage over the last two decades.

Figure 3 shows calculated CDI (Compiled Drought Index) time series for Hargeisa station for monthly time units. CDI is a Microsoft Excel-based software package that provides an easy-to-use means of calculating indices for monitoring drought. It was developed by FAOSWALIM.

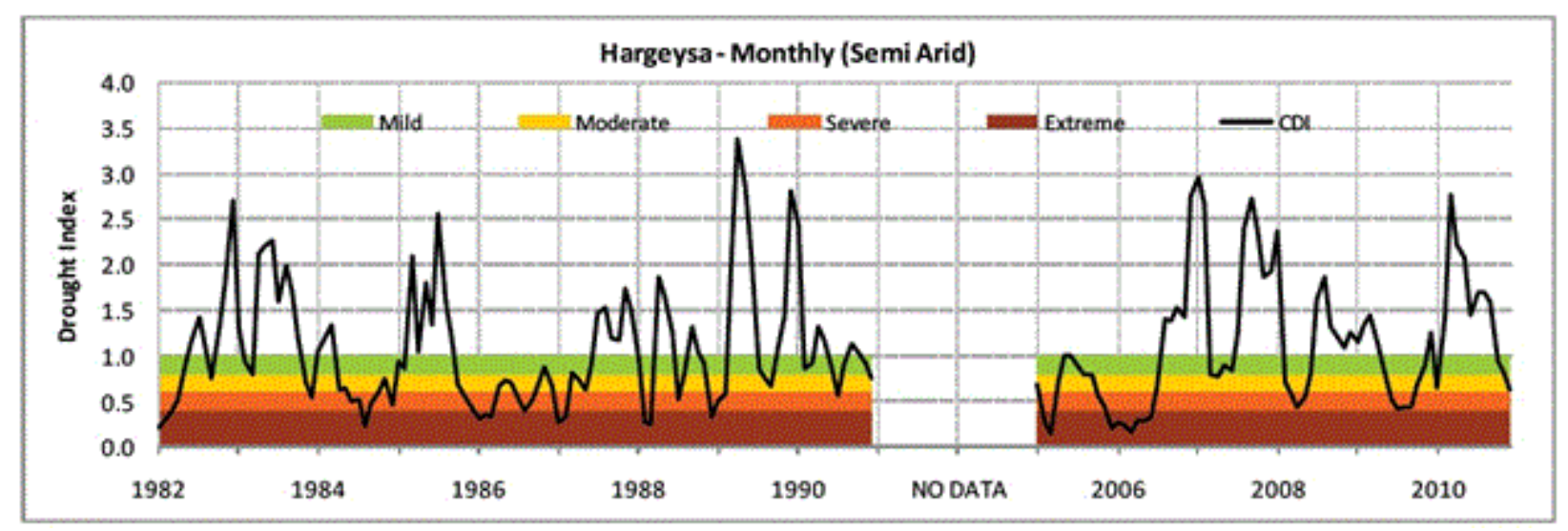

Figure 3: Calculated CDI time series for Hargeisa station for monthly time units.

Severities of meteorological drought for Somaliland were also calculated using (SPI). Based on the historical rainfall data, it was easy to analyze whether the probability of rainfall is less than or equal to a certain amount. The calculation of SPI values for the Gu and Deyr rainy seasons were carried out using CHIRPS gridded rainfall dataset to get a general view of the alternation of moist and dry periods. Figures 4-7 depict the comparison of SPI and rainfall deviations for Somaliland during 2015/2016 Deyr and Gu rainy seasons.

During the $2015 \mathrm{Gu}$ and Deyr rainy seasons, the values of SPI in Somaliland are more stretched between 1.5 to -1.5 as showed in Figures 4 and 5. On the other hand, during the $2016 \mathrm{Gu}$ and Deyr rainy seasons, the values of SPI in Somaliland are more stretched between 2.0 to -1.5 and 1.0 to -1.0 respectively as can be seen in Figures 6 and 7. In the agro-pastoral areas of Somaliland, the SPI values tend to be higher $>1.5$, for the events of excess rainfall.

It also interests to note that the SPI value was lower in eastern parts of Somaliland than the other parts of Somaliland during the analysed period accept 2015 Deyr rainy season where large portion of Sanaag and few pocks in Togdheer regions have recorded higher positive value of SPI. With increasing the rain in the Deyr 2015, the drought value decreased in the western and southern parts. With decreasing rain in $\mathrm{Gu}$ (2016), the drought increased in the 2016 Deyr in the eastern regions.

On the other hand, rainfall data of 10 years of for four different cities in the eastern and western parts of Somaliland were also analysed specifically for drought investigation, which may be used for long term planning of irrigation system in the area.

During 10 years period, different categories of drought year was experienced for the four cities. Table 4 shows the characteristics of drought in 12 month time scale from 2007 to 2016 for four different cities in Somaliland namely Borama and Gebiley in the west and Odweyne and Erigavo in the East. 
Citation: Abdulkadir G (2017) Assessment of Drought Recurrence in Somaliland: Causes, Impacts and Mitigations. J Climatol Weather

Page 5 of 12

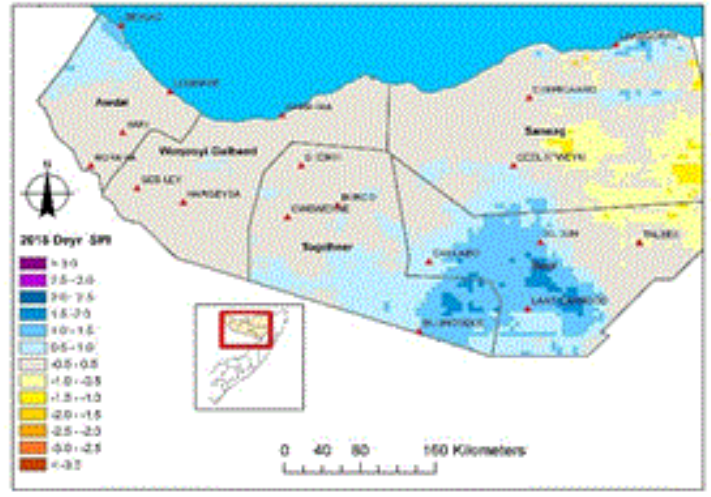

Figure 4: Variation of SPI during Deyr season in 2015.

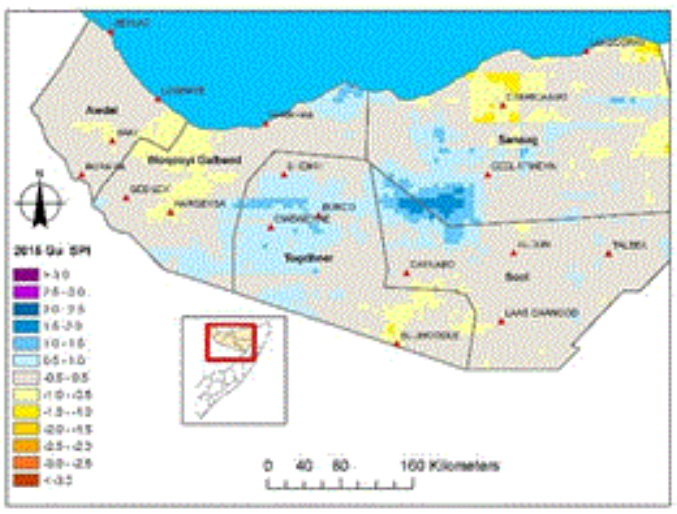

Figure 5: Map of Somaliland showing variation of SPI during Gu season in 2015.

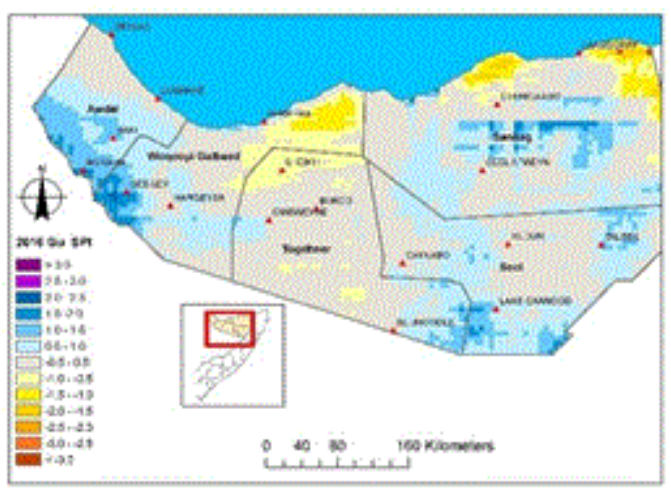

Figure 6: Variation of SPI during Gu season in 2016.
Plotting a time series of years against SPI gives a good indication of the drought history of a particular station.

Result show that the most severe drought values had occurred in 2009 for Gebiley with SPI values of -1.92 and with total rainfall of $293.5 \mathrm{~mm}$ and for Borama in 2014 and 2015 with SPI values of -1.60 and -1.94 and with total rainfall of $340 \mathrm{~mm}$ and $299 \mathrm{~mm}$ respectively (Figure $8 \mathrm{a}$ and $8 \mathrm{~b}$ ).

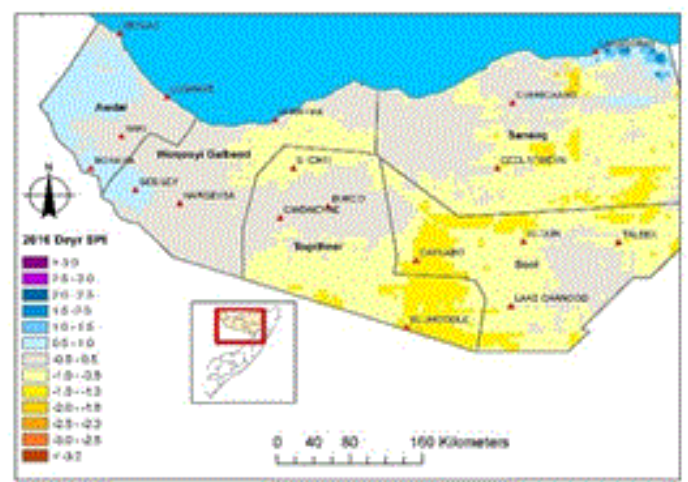

Figure 7: Map of Somaliland showing variation of SPI during Deyr season in 2016 .

Whereas severe drought was also seen in 2008, 2015 and 2016 in Odweyne district in Togdheer region with SPI values of $-1.50,-1.93$ and-1.55 and with total rainfall of $144 \mathrm{~mm}, 85.5 \mathrm{~mm}$ and $137 \mathrm{~mm}$ respectively (Figure $8 \mathrm{c}$ ).

In Erigavo, a moderate drought was observed during 2012 and 2016 with total rainfall of $177.4 \mathrm{~mm}$ and $187.5 \mathrm{~mm}$ respectively (Figure $8 \mathrm{~d}$ ). Moderate drought was also observed in Borama in 2009, 2011 and 2016 with total rainfall of $414.5 \mathrm{~mm}, 405.5 \mathrm{~mm}$ and $370.5 \mathrm{~mm}$ respectively.

Similarly, moderate drought was also observed in Odweyne in 2007, 2009 and 2016 with total rainfall of $205 \mathrm{~mm}, 189.5 \mathrm{~mm}$ and $332 \mathrm{~mm}$ respectively.

Is also interesting to note that there was no severe or moderate drought occurred in the year of 2013. But it has only been a low moisture year for Gebiley and Borama with SPI values of 0.07 and 0.71 with total rainfall of $461.5 \mathrm{~mm}$ and $624.8 \mathrm{~mm}$ respectively.

While the same year of 2013, the eastern cities of Odweyne and Erigavo has experienced a year with intense moist with SPI values of 2.02 and 2.86 (with total rainfall of $627 \mathrm{~mm}$ and $443 \mathrm{~mm}$ ).

\section{Seasonal (Gu and Deyr) rainfall distribution and coefficient of rainfall variation}

Figures 9 and 10 show the average seasonal (Gu and Deyr) rainfall distribution in Somaliland for the period between 1981 and 2016. During the Gu rainy season, much of the rains are concentrated in the agro-pastoral areas of Awdal and Waqoyi-Galbed regions as well as parts of Togdheer region particularly the areas around sheikh with an average rainfall of between 157-223 mm (Figure 9). 
Citation: Abdulkadir G (2017) Assessment of Drought Recurrence in Somaliland: Causes, Impacts and Mitigations. J Climatol Weather

Page 6 of 12

\begin{tabular}{|c|c|c|c|c|c|c|c|c|c|}
\hline City & Year & $\begin{array}{l}\text { Annual rainfall } \\
\text { total }(\mathrm{mm})\end{array}$ & $\begin{array}{l}\text { Drought } \\
\text { severity index } \\
\text { (SPI) }\end{array}$ & $\begin{array}{l}\text { Drought } \\
\text { category }\end{array}$ & City & Year & $\begin{array}{l}\text { Annual } \\
\text { rainfall total } \\
(\mathrm{mm})\end{array}$ & $\begin{array}{l}\text { Drought } \\
\text { severity index } \\
\text { (SPI) }\end{array}$ & Drought category \\
\hline \multirow{10}{*}{ Gebiley } & 2007 & 697.8 & 2.86 & $\begin{array}{l}\text { Intensely } \\
\text { moist }\end{array}$ & \multirow{10}{*}{ Odweyne } & 2007 & 205 & -1.05 & Moderate drought \\
\hline & 2008 & 452 & -0.04 & $\begin{array}{l}\text { Borderline } \\
\text { drought }\end{array}$ & & 2008 & 144 & -1.5 & Severe drought \\
\hline & 2009 & 293.5 & -1.92 & $\begin{array}{l}\text { Severe } \\
\text { drought }\end{array}$ & & 2009 & 189.5 & -1.17 & Moderate drought \\
\hline & 2010 & 536.5 & 0.95 & Low moisture & & 2010 & 259.5 & -0.66 & Borderline drought \\
\hline & 2011 & 434.5 & -0.25 & $\begin{array}{l}\text { Borderline } \\
\text { drought }\end{array}$ & & 2011 & 434.5 & 0.62 & Low moisture \\
\hline & 2012 & 511.5 & 0.66 & Low moisture & & 2012 & 332 & -0.13 & Moderate drought \\
\hline & 2013 & 461.5 & 0.07 & Low moisture & & 2013 & 627 & 2.02 & Intensely moist \\
\hline & 2014 & 411 & -0.53 & $\begin{array}{l}\text { Borderline } \\
\text { drought }\end{array}$ & & 2014 & 281 & -0.5 & Borderline drought \\
\hline & 2015 & 392 & -0.75 & $\begin{array}{l}\text { Borderline } \\
\text { drought }\end{array}$ & & 2015 & 85.5 & -1.93 & Severe drought \\
\hline & 2016 & 572 & 1.37 & $\begin{array}{l}\text { Moderately } \\
\text { moist }\end{array}$ & & 2016 & 137 & -1.55 & Severe drought \\
\hline \multirow{10}{*}{ Borama } & 2007 & 432.6 & -0.85 & $\begin{array}{l}\text { Borderline } \\
\text { drought }\end{array}$ & \multirow{10}{*}{ Erigavo } & 2007 & 277.5 & 0.3 & Low moisture \\
\hline & 2008 & 493.5 & -0.36 & $\begin{array}{l}\text { Borderline } \\
\text { drought }\end{array}$ & & 2008 & 296.5 & 0.59 & Low moisture \\
\hline & 2009 & 414.5 & -1 & $\begin{array}{l}\text { Moderate } \\
\text { drought }\end{array}$ & & 2009 & 283 & 0.38 & Low moisture \\
\hline & 2010 & 781.1 & 1.98 & Very moist & & 2010 & 350 & 1.42 & Moderately moist \\
\hline & 2011 & 405.5 & -1.07 & $\begin{array}{l}\text { Moderate } \\
\text { drought }\end{array}$ & & 2011 & 218 & -0.62 & Borderline drought \\
\hline & 2012 & 456.8 & -0.65 & $\begin{array}{l}\text { Borderline } \\
\text { drought }\end{array}$ & & 2012 & 177.4 & -1.25 & Moderate drought \\
\hline & 2013 & 624.8 & 0.71 & Low moisture & & 2013 & 443 & 2.86 & Intensely moist \\
\hline & 2014 & 340 & -1.6 & $\begin{array}{l}\text { Severe } \\
\text { drought }\end{array}$ & & 2014 & 349 & 1.41 & Moderately moist \\
\hline & 2015 & 299 & -1.94 & $\begin{array}{l}\text { Severe } \\
\text { drought }\end{array}$ & & 2015 & 241.5 & -0.26 & Borderline drought \\
\hline & 2016 & 370.5 & -1.35 & $\begin{array}{l}\text { Moderate } \\
\text { drought }\end{array}$ & & 2016 & 187.5 & -1.1 & Moderate drought \\
\hline
\end{tabular}

Table 4: Variation of SPI for four cities in Somaliland during the period between 2007 and 2016.

In contrast, low average seasonal distribution was seen in the areas along the coast of Somaliland and few pockets in the eastern and southern part of Sool and Sanaag regions respectively.

Meanwhile, during the Deyr season, much of the rains are concentrated in the areas around sheikh and southern parts of Togdher and Sool region with an average rainfall of between 69-104 $\mathrm{mm}$. Similarly, during the Deyr season, the eastern parts of Somaliland shows low average seasonal distribution compared to western parts particularly the northern parts of Sanaag region and parts of eastern Sool region (Figure 10).

In Somaliland, climate variability and change on the other hand greatly influence social and natural environments, with subsequent impacts on natural resources. Figures 11 and 12 show the coefficient of rainfall variability over Somaliland during the Deyr and Gu rainfall season. 
Citation: Abdulkadir G (2017) Assessment of Drought Recurrence in Somaliland: Causes, Impacts and Mitigations. J Climatol Weather

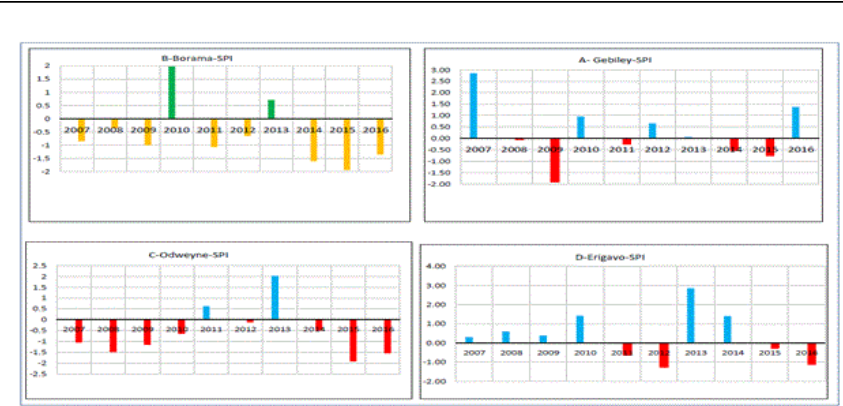

Figure 8: Variation of SPI values for Four Cities in Somaliland during the period between 2007 and 2016.

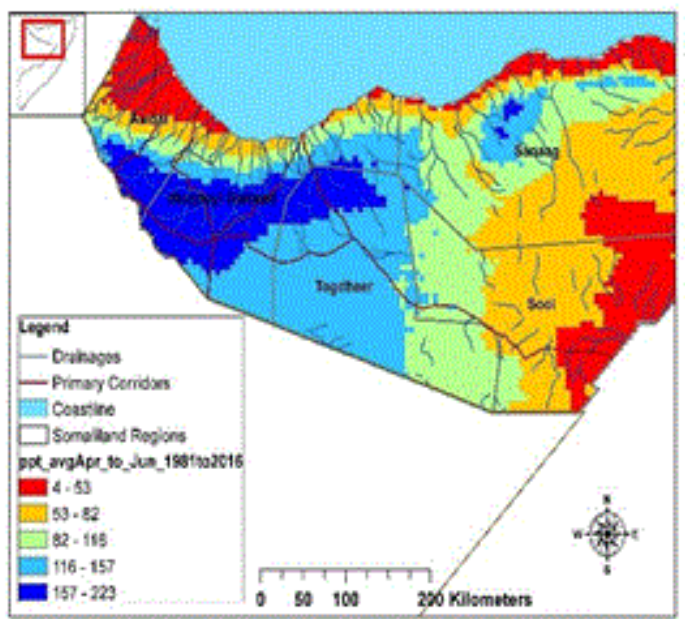

Figure 9: Average Seasonal distribution of rainfall over Somaliland in $\mathrm{Gu}$ season from 1981 to 2016.

During the Deyr season, the analysis of coefficient of variation from 1981 to 2016, there was high variability in Awdal region and some parts of Waqoyi Galbed region as well as the coastal areas of Somaliland (Figure 11).

The higher coefficient of rainfall variability implies that the precipitation is likely to be irregular in these areas; heavy rainfall at certain periods and low or no rainfall in some other years. Similarly, during the $\mathrm{Gu}$ season, coefficient of variation from the same period (1981 to 2016) was high in Awdal region, particularly in the coastal areas (Figure 12).

\section{Seasonal rainfall performance}

The 2016 Deyr rainfall performance has been mixed across Somaliland. In the eastern half of Somaliland (except for sheikh), the performance of the rainfall was poor as it was recorded below average rains during the Deyr season.

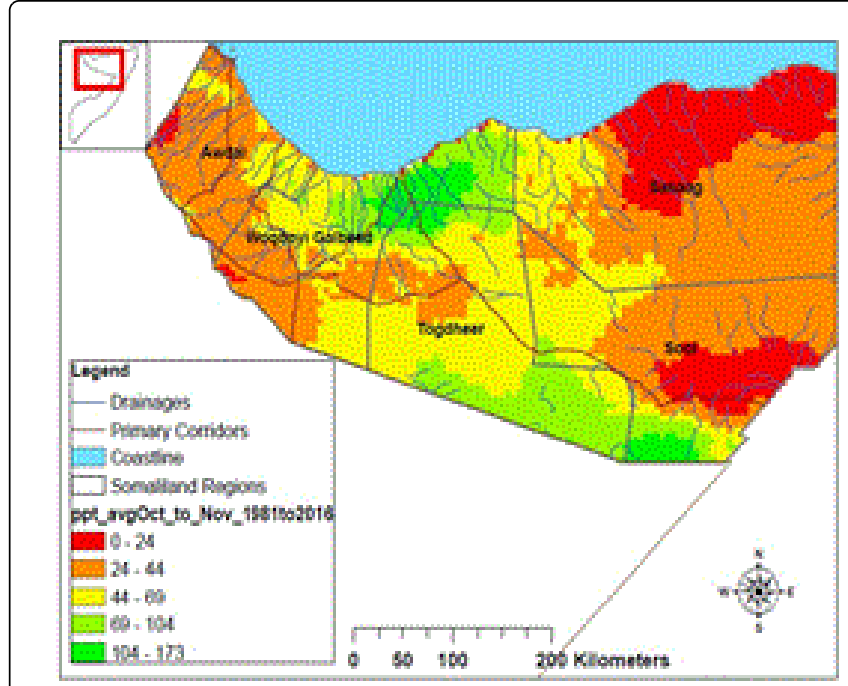

Figure 10: Average Seasonal distribution of rainfall over Somaliland in $\mathrm{Gu}$ season from 1981 to 2016.

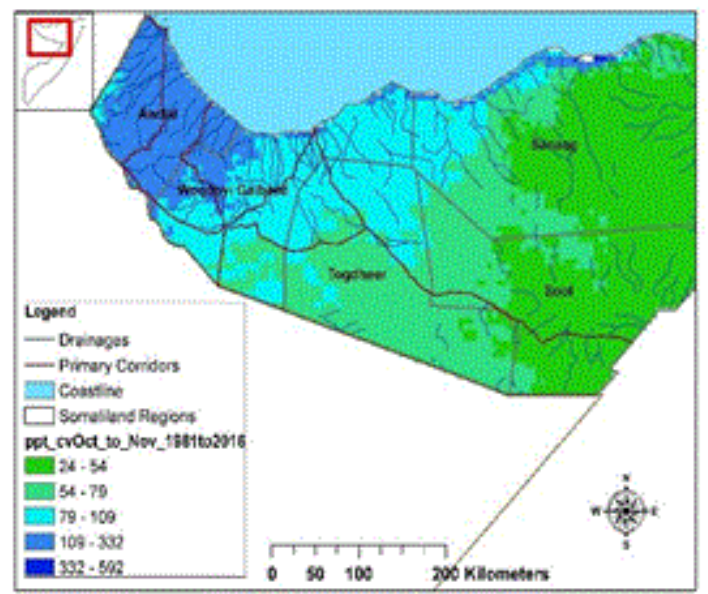

Figure 11: Variability of rainfall over Somaliland in Gu season from 1981 to 2016.

Most of these pastoral regions have also experienced rainfall deficits in the previous $\mathrm{Gu}$ rains. The poor rains of 2016 Deyr have also impacted the major agro-pastoral zones of Guban and West Golis in Awadal and Waqoyi galbed regions.

The areas with rainfall deficits include Odweyne $(8 \mathrm{~mm})$, Erigavo $(12 \mathrm{~mm})$, Aynabo $(24 \mathrm{~mm})$ and El-Afwayne $(0 \mathrm{~mm})$ as well as their surroundings (Figure 13). 


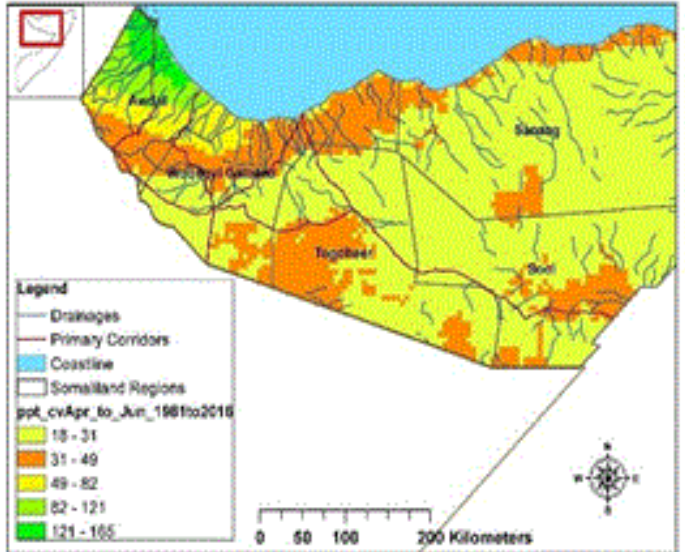

Figure 12: variability of rainfall over Somaliland in Gu season from 1981 to 2016.

This situation of long-term persistent dryness has put local livelihoods under considerable stress, especially in the agro pastoral areas of western Somaliland where considerable number of migrants from eastern regions come to these areas.

Insufficient rain during Deyr season has also led significantly to large moisture deficits and abnormal dryness, which have negatively affected cropping activities in agro pastoral areas of Somaliland.

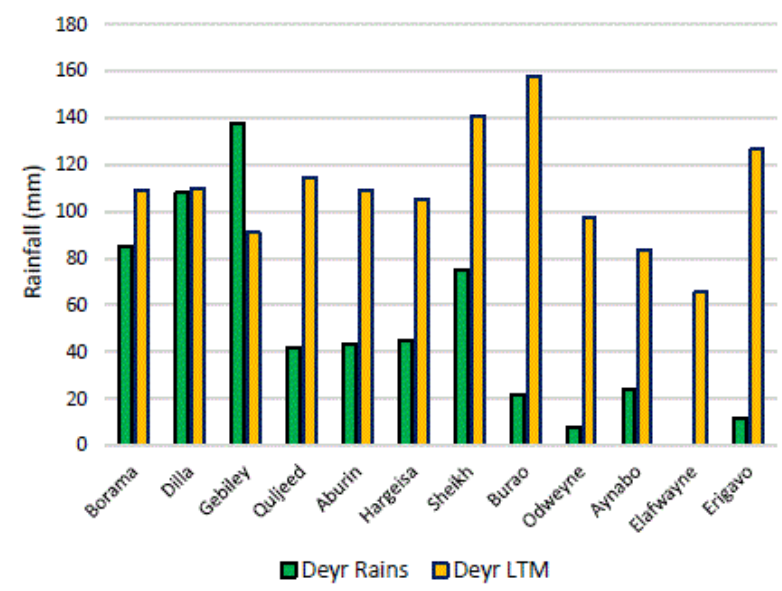

Figure 13: Deyr rainfalls performance compared to LTM in Somaliland.

On the other hand during the $2016 \mathrm{Gu}$ season, good rains were received in parts of Somaliland particularly the western regions. Although the spatial distribution of rainfall was quite good, the accumulative rainfall amounts for some areas were remained depressed following prolonged dry period in preceding months.

Most of stations in the west of Somaliland recorded significant rains while the eastern regions have received little rains. The agro-pastoral areas of Guban and West Golis, which have been dry for a long period of time, received some moderate to heavy rains which caused flash floods.

Dilla, Aburin and Gebiley have recorded the highest amounts of rainfall in Somaliland during the $2106 \mathrm{Gu}$ rainy season.

While other nearby areas such as Hargeisa recorded significant amounts of rainfall. Moreover, the rains were well distributed across Somaliland during the $2016 \mathrm{Gu}$ rainy season. The stations that recorded highest amounts of rainfall include Gebiley $(310 \mathrm{~mm})$, Dila (306 mm), Aburin $(292 \mathrm{~mm})$ and Hargeisa $(271.5 \mathrm{~mm})$.

Some stations are however recorded below average rains during the $2016 \mathrm{Gu}$ rainy season. These stations include; El-Afwayne $(25.5 \mathrm{~mm})$, Aynabo $(75 \mathrm{~mm})$, Sheikh $(89 \mathrm{~mm})$ and Odweyne $(119 \mathrm{~mm})$, as seen in Figure 14.

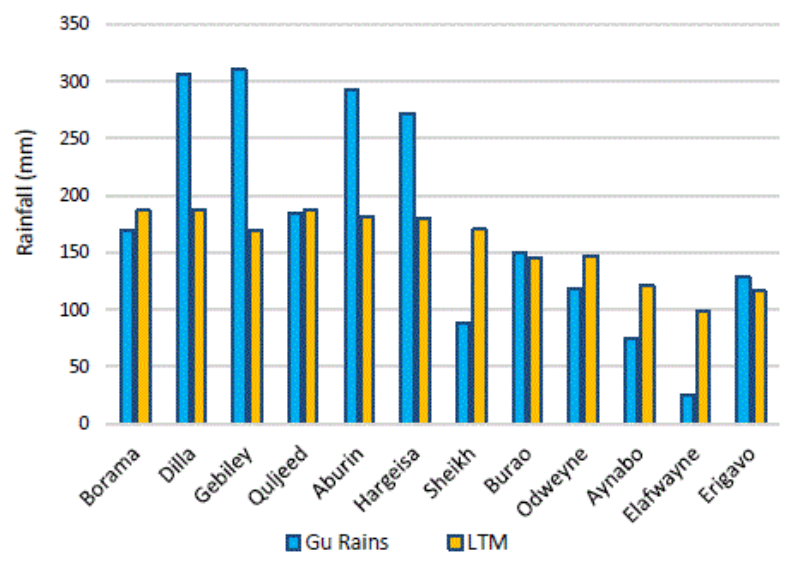

Figure 14: $\mathrm{Gu}$ rainfalls performance compared to LTM in Somaliland.

It is also important to mention that the March-May (2017) rainfall for the Greater Horn of Africa, which is also the main rainy season for Somaliland as it covering most of the Gu rainfall season, forecasts on below average rainfall for Somaliland (Figure 15).

The regional consensus climate outlook for the March to May 2017 season indicates an increased likelihood of below normal to near normal rainfall over Somaliland (yellow zones in Figure 15). Increased probabilities of near to above normal rainfall are indicated over parts of Galmudug and Puntland (the blue zones in Figure 15).

The UK-Met Office forecasts indicate below to near average rainfall for most of parts of Somaliland in broad agreement with the GHACOF forecast. Whereas combining a number of models into a single "ensemble" forecast (WMO) allows a better picture.

Overall, most likely outcome for $2017 \mathrm{Gu}$ rainy season is for below average rainfall for Somaliland. The unfavourable rainfall forecast is further compounded by increased expectations of above-average temperatures, which could further delay crop development, negatively affecting yields and harvests (Figures 16-18). 


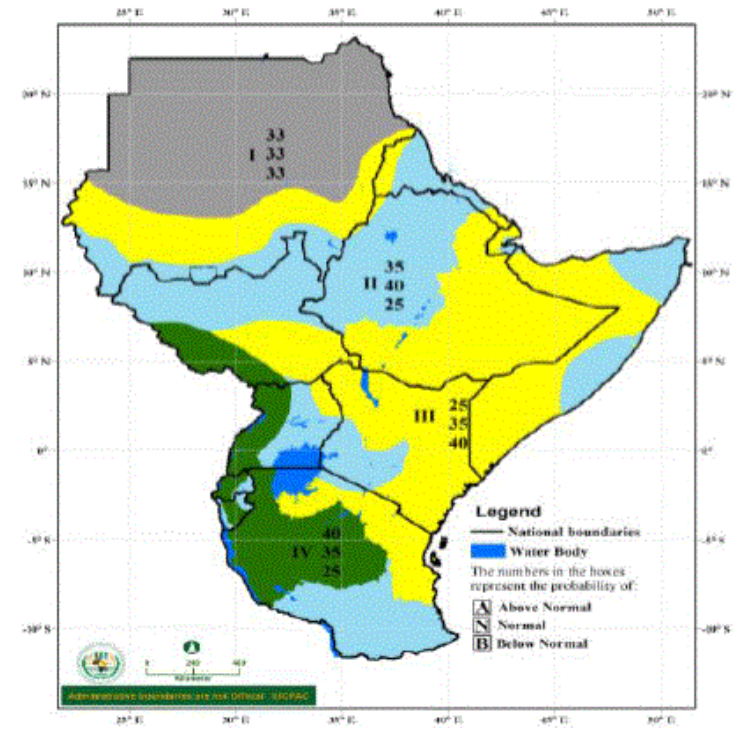

Figure 15: The GHA region rainfall outlook for MAM 2017 season.

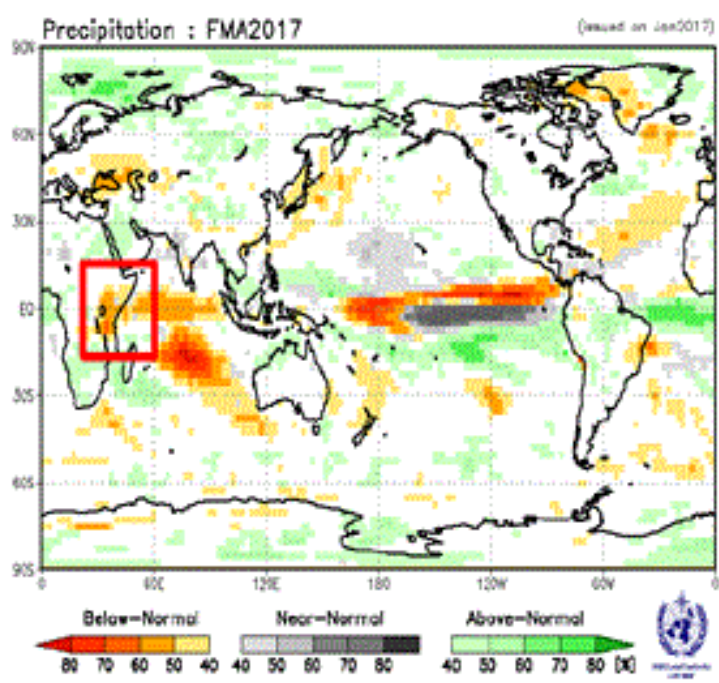

Figure 16: Seasonal forecasts for Feb-April 2017, Rainfall: WMO.

\section{Discussion}

Extreme weather events have become more frequent and more intense since the middle of the 20th century worldwide and are expected to become even more pronounced throughout the 21 st century due to climate change [13]. Particularly, the number and length of warm weather spells and heat waves have increased globally. In Africa, drought is a part of natural climatic variability on the continent, which is quite high at intra-annual, decadal and century timescales [14]. In general, drought is one of the most complex natural phenomena, that is difficult to quantify and manage, and has multiple and extreme social and economic consequences. The magnitude of these impacts is determined by the level of development, population density and structure, demands on water, government institutional capacity.

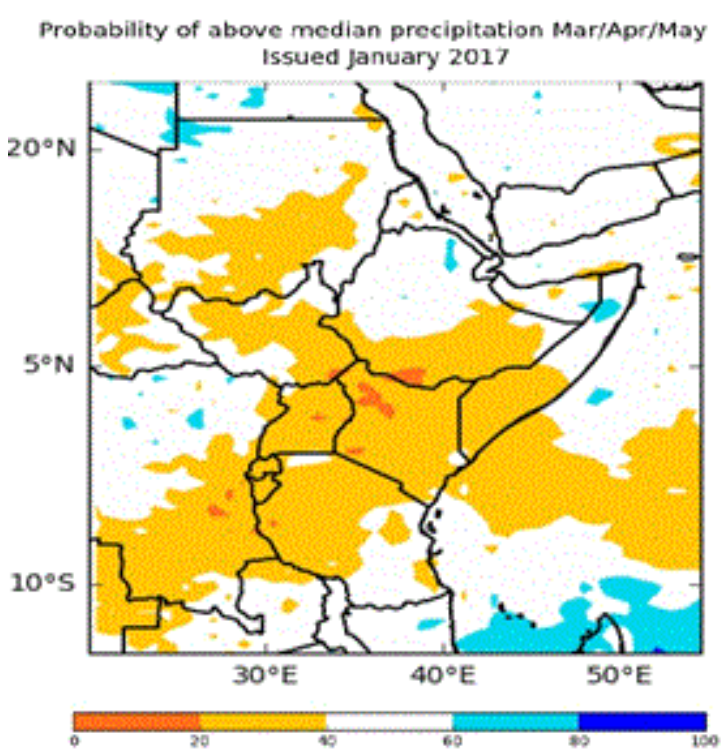

Figure 17: Seasonal forecasts for March-May 2017, Rainfall: UK Met Office.

Many studies attempted to investigate the natural causes that could be associated with droughts in Africa [15-21]. Some of them also focused on anthropogenic factors, such as climate change, aerosol emissions, land use practices and resulting land-atmosphere interactions, contributing to drought inducing mechanisms $[16,17,22-24]$. The review of these studies revealed that there are a number of factors contributing to inducing drought conditions. However, despite regional differences in the factors causing droughts in a specific region, El Niño-Southern Oscillation (ENSO) and SSTs are regarded major influencing factors across the continent.

Somaliland is, however, vulnerable to drought recurrence, mainly because of its geographical location, the fragile environment and the variable climate. The main underlying causes of most droughts in Somaliland can be related to changing weather patterns manifested through the excessive build-up of heat on the earth's surface, meteorological changes which result in a reduction of rainfall, and reduced cloud cover, all of which results in greater evaporation rates. Furthermore, the resultant effects of drought are aggravated by human activities such as deforestation, overgrazing and poor cropping methods, which diminish water retention of the soil, and inappropriate soil conservation techniques, which lead to soil degradation. Frequent drought occurs in Somaliland as it locates in arid regions where the rainfall usually performs poorly and is accompanied by relatively high evaporation rates for prolonged periods. However, in most cases, drought is caused by a deficiency of either precipitation or an inadequacy of inland water resources supplies for a prolonged period. Since most of the surface water resources in Somaliland are usually sustained by rainfall, inadequate rainfall is usually the major cause of drought.

Droughts have disastrous impacts on Somaliland communities. Therefore, in order to analyze the severities of meteorological drought, the SPI values of different years and seasonal were analyzed in this 
study with actual rainfall and rainfall deviation from normal particularly drought prone areas. The intensity of the drought event can be classified according to the magnitude of the negative SPI values such that the larger the negative SPI values the more serious the event would be. A drought event occurs when the SPI is continuously reaches an intensity of -1.0 or less. The event ends when the SPI becomes positive. Each drought event, therefore, has a duration defined by its beginning and end, and intensity for each month that the event continues. In Somaliland, the droughts that occurred in 19731974, 1984, 1991, 2010/2011 and 2016/2017 were most intense and widespread.

Analysis of 10 years rainfall data for four different cities in Somaliland was performed specifically to discover how drought was recurring during these periods. During the analyzed periods, different categories of drought year were experienced for the four cities. The most severe drought had occurred in 2009 for Gebiley and 2014 and 2015 for Borama. Whereas severe drought was seen in 2008, 2015 and 2016 in Odweyne district. In Erigavo, a moderate drought was observed during 2012 and 2016. While another moderate drought was also observed in Borama in 2009, 2011 and 2016. Similarly, moderate drought was also spotted in Odweyne in 2007, 2009 and 2016.

From the rainfall analysis using SPI, it was found that even the very small amount of rainfall that was inadequate to maintain enough soil moisture resulted in SPI values of around -1.5 which otherwise would represent extreme dryness with the values around -2.0 and below. Similarly, excess rainfall events in Somaliland had a SPI value of around 1.5. It is obvious that a reduction in precipitation with respect to the normal precipitation amount is the primary driver of drought, resulting in a successive shortage of water for different natural and human needs. Deficit of rainfall over a period of time at a certain location could lead to various degrees of drought conditions, affecting water resources, agriculture and socioeconomic activities. As a result, the rainfall patterns, particularly rain failure or erratic rainfall are frequently the cause of recurrent droughts in Somaliland. Environmental degradation is accelerated during periods of drought due to poor land use activities such as cutting down of trees for fuel; wood and charcoal burning for income and overgrazing.

In 2015/2016 drought, many people had to sell what little they had, making them even more vulnerable to the next drought and would also mean that fewer people have enough animals to be able to donate to others in need. Meanwhile, livelihoods have suffered very much from consecutive droughts in Somaliland and most people do not perceive any future in pastoralism as many pastoralists switched to charcoal production to compensate for economic losses from pastoralism.

For many years, mobile pastoral communities in Somaliland have been coping with changing environmental conditions, and as a result they have a long established capacity for adaptation. However, changes in their environments in recent years have weakened their adaptive strategy, which is now increasing their vulnerability. Normally, when dangerous hazards, like droughts occur, the whole agro-pastoral production system collapses with disastrous consequences for the affected populations. Enormous financial resources are then required for humanitarian aid and even more to recover the production systems and livelihoods of the affected communities. Within the Somali context, local communities, diaspora groups, local organizations and local authorities are typically the first responders in crises [25].

Currently, there are many challenges that face Somaliland when it comes drought mitigation. The main challenge is to convince policy and other decision makers that investments in mitigation are more cost effective than post-impact assistance or relief programmes. The process of dealing with drought during the disaster management would only be effective when an appropriate knowledge and required technology is readily available to improve preparedness and mitigation impacts.

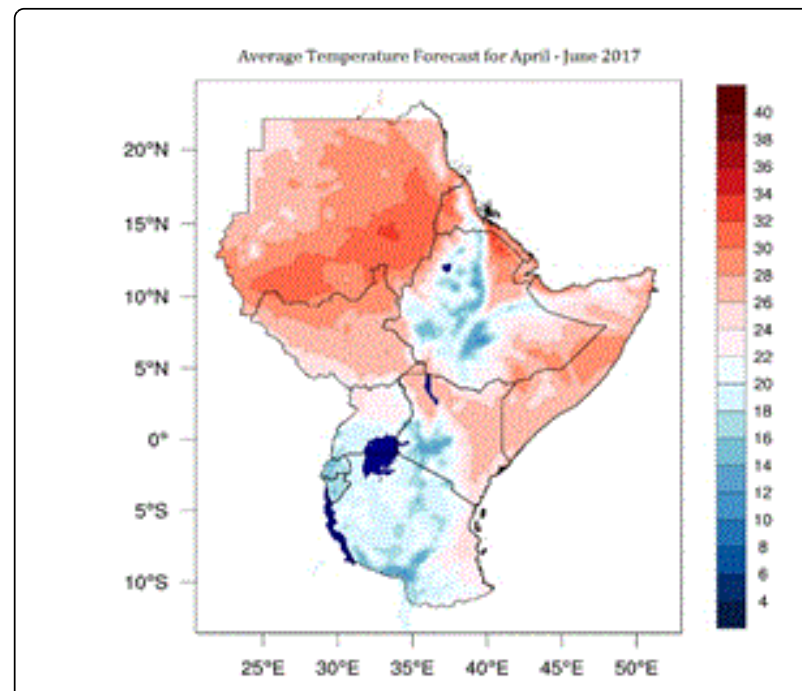

Figure 18: Average temperature forecast for April-June 2017 for GHA.

Structural mitigation measures is required in order to lessen the drought recurrence in Somaliland such as provision of an appropriate crops to farmers and engineering projects such as sand dams to harvest rain water during the rainy season. It is also required non- structural mitigations such as policies, knowledge development and functioning practices assumed to limit the adverse impacts of natural hazards. On the other hand, access to climate information is important for effective preparedness and response to adverse weather trends and disasters by the vulnerable communities in Somaliland.

2016 Deyr were well below average and pessimistic forecasts for the next rainfall season raise the possibility of a third poor rainfall season for Somaliland that would lead to a situation similar to the 2010-2011 humanitarian crisis. Therefore, early action is key to prevent the situation from getting as bad as in 2011 as the humanitarian response was too slow. It is also important to underline that the forecasted performance of the $2017 \mathrm{Gu}$ rainfall is expected to have mixed implications for food security, livestock production and productivity, water, and health in different parts of Somaliland. Thus, in order reduce the impacts of the forecasted rainfall in Somaliland, there is need to strengthen disaster risk reduction strategies including response capacities, coordination, resource mobilization, communication and advocacy at national level (Figure 19). On the other hand, drought predictions based on the global climate models simulations show varying results and therefore remain uncertain for Somaliland. The available evidence from the past clearly shows that the Somaliland is very likely to face extreme and widespread droughts in the future. The vulnerability is likely to increase due to fast growing populations, increasing water demands and degradation of land and environmental resources. 


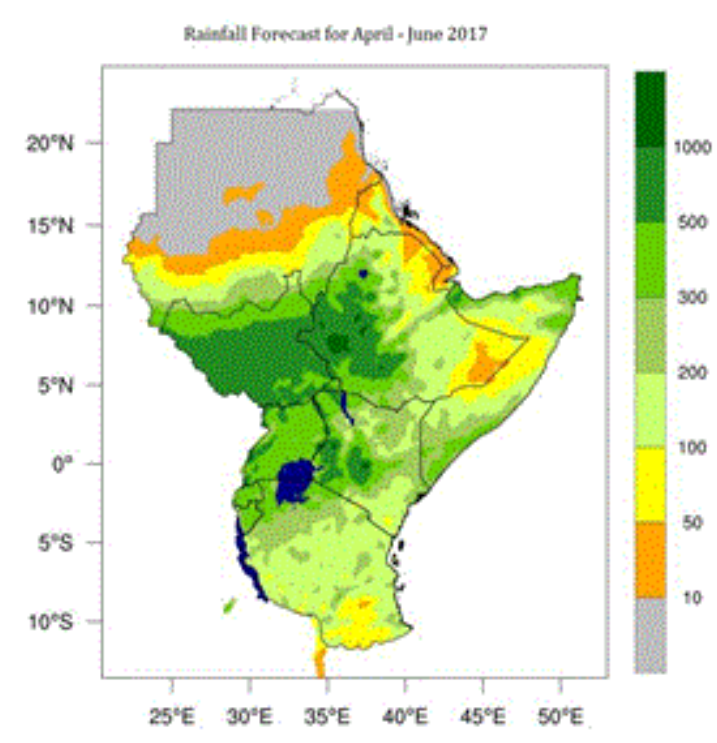

Figure 19: Rainfall forecast for April-June 2017 for GHA.

\section{Recommendations}

The ministry of Agriculture of Somaliland and NERAD, as the responsible institutions for provision of met services and Early Warning Systems (EWS), should provide farmers and pastoralists simple and understandable (Somali language), timely and reliable weather forecast information to facilitate early intervention by the government and its partners.

In order to strengthen the resilience of the people, Governments of Somaliland is strongly advised to increase investment in community infrastructure and social services with a focus on improving rural communities by providing training to farmers, pastoralists in special techniques such as soil and water conservation, water harvesting that can play a major role in drought disaster mitigation.

More importantly, there is an urgent and dire need to progress on various fronts of drought mitigation such as early warning and forecasting, long-term planning and capacity building. The global climate models simulations show varying results and therefore remain uncertain for Somaliland. The available evidence from the past clearly shows that the Somaliland is very likely to face extreme and widespread droughts in the future. The vulnerability is likely to increase due to fast growing populations, increasing water demands and degradation of land and environmental resources.

\section{Conclusion}

Conclusions of this paper is that Somaliland's aridity and drought recurrence have been increasing significantly during the past decades and this attributed to widespread drying particularly the eastern regions. The vulnerability to droughts is high in Somaliland due to poverty and large dependency on rain fed agriculture. Furthermore, water scarcity caused by aridity and recurrent droughts has been threatening food security by reducing agricultural productivity. The drought trends are also projected to continuously increase in the next coming years due to the climate change. However, if proper and detailed study of various rainfall data is analyzed, the severity of droughts can be known and therefore various measures can be taken to cope up with the problems of drought. The study has also noted that the capacity of Somaliland people to face these recurrent droughts compounded by shortcomings in government's capacity to install longterm drought mitigation measures have been weakened as the population resilience mechanism reduced. As a result, a contingency planning and management of droughts is essentially required.

\section{Acknowledgement}

I am grateful to the many people who have contributed directly or indirectly to the preparation of this publication. Special thanks go to Mr. Ali Ismail from FAO-SWALIM as well as Dr Philip Amondi from IGAD Climate Prediction and Application Center (ICPAC).

\section{Disclaimer}

The opinions and recommendations expressed in this study are those of the author and do not necessarily reflect the views or policies of FAO. The author and FAO do not assume any responsibility for the geographic borders and names used for the purpose of mapping in this publication.

\section{References}

1. Palmer WC (1965) Meteorological Drought, Research Paper No. 45. U.S. Department of Commerce Weather Bureau: Washington, DC, USA.

2. Heim RR (2002) A review of twentieth-century drought indices used in the United States. Bull Amer Meteorol Soci 83: 1149-1165.

3. IFRC (2011) Drought in the Horn of Africa: Preventing the next disaster. International Federation of the Red Cross and Red Crescent Societies, Geneva, Switzerland.

4. Muchiri PW (2007) Climate of Somalia. Technical Report No W-01, FAO-SWALIM, Nairobi, Kenya.

5. Oduor AR, Gadain HM (2007) Potential of Rainwater Harvesting in Somalia, A Planning, Design, Implementation and Monitoring Framework, Technical Report NoW-09. FAO- SWALIM, Nairobi, Kenya.

6. Saleem U (2016) Territorial diagnostic report of the land resources of Somaliland. FAO-SWALIM, Nairobi, Kenya.

7. Funk C, Peterson P, Landsfeld M, Pedreros D, Verdin J, et al. (2015) The climate hazards infrared precipitation with stations-a new environmental record for monitoring extremes. Sci Data 2: 150066.

8. McKee BT, Doesken JN, Kleist J (1993) The relationship of drought frequency and duration to time scales, Proceedings of ninth Conference on Applied Climatology, Boston. 179-184.

9. Abawi Y, Dutta S, Ritchie J (2003) Potential use of climate forecasts in water resources management. In Stone R and Patridge I (eds.) Science for drought.

10. Sharma A, Dadhwal VK, Jeganathan C, Tolpekin V (2009) Drought monitoring using standardized precipitation index: a case study for the state of Karnataka, India.

11. Giddings L, Soto M, Rutherford BM, Maarouf A (2005) Standardized precipitation index Zones for Mexico. Atmosfera pp: 33-56.

12. Akhatari R, Bandarabadi SR, Saghafian B (2008) Spatio-temporal pattern of drought in north-eastern Iran. Option Mediterraneennes. Options Series A 80: 71-77.

13. Intergovernmental Panel on Climate Change (IPCC) (2012) Managing the risks of extreme events and disasters to advance climate change adaptation p: 582.

14. Nicholson SE (2000) The nature of rainfall variability over Africa on time scales of decades to millenia, Global Planet Chan 26: 137-158. 
Citation: Abdulkadir G (2017) Assessment of Drought Recurrence in Somaliland: Causes, Impacts and Mitigations. J Climatol Weather Forecasting 5: 204. doi:10.4172/2332-2594.1000204

Page 12 of 12

15. Caminade C, Terray L (2010) Twentieth century Sahel rainfall variability as simulated by ARPEGE AGCM, and future changes. Clim Dynam 35: 75-94.

16. Dai A (2011) Drought under global warming: a review, Wiley Interdisciplinary Reviews. Clim Change 2: 45-65.

17. Dai A (2013) Increasing drought under global warming in observations and models. Nat Clim Change 3: 52-58.

18. Dutra E, Magnusson L, Wetterhall F, Cloke HL, Balsamo G, et al. (2011) The 2010-2011 drought in the Horn of Africa in ECMWF reanalysis and seasonal forecast products. Int J Climatol 33: 1720-1729.

19. Giannini A, Biasutti M, Verstraete MM (2008) A climate modelbased review of drought in the Sahel: Desertification, the regreening and climate change. Global Planet Change 64: 119-128.

20. Giannini A, Salack S, Lodoun T, Ali A, Gaye AT, et al. (2013) A unifying view of climate change in the Sahel linking intra-seasonal, interannual and longer time scales. Environ Res Lett 8: 024010.
21. Hastenrath S, Polzin D, Mutai C (2005) Diagnosing the 2005 Drought in Equatorial East Africa. J Climate 20: 4628-4637.

22. Hwang YT, Frierson DMW, Kang SM (2013) Anthropogenic sulfate aerosol and the southward shift of tropical precipitation in the late 20th century. Geophys Res Lett 40: 1-6.

23. Lebel T, Cappelaere B, Galle S, Hanan N, Kergoat L, et al. (2009) AMMA$\mathrm{CATCH}$ studies in the Sahelian region of West- Africa: An overview. J Hydrol 375: 3-13.

24. Zeng N (2003) Drought in the Sahel. Science 302: 999-1000.

25. Darcy J, Bonard P, Dini S (2012) Real Time Evaluation of the Humanitarian Response to the Horn of Africa Drought Crisis: Somalia 2011-2012. NY, USA: IASC. 